Lenka EHRENBERGEROVÁ ${ }^{1}$

Martin ŠENFELDR ${ }^{1}$

Hana HABROVÁ ${ }^{1}$

${ }^{1}$ Mendel University in Brno

Department of Forest Botany,

Dendrology and Geobiocoenology

Zemědělská 3, Brno 61300

Czech Republic

\section{Impact of tree shading on the microclimate of a coffee plantation: a case study from the Peruvian Amazon}

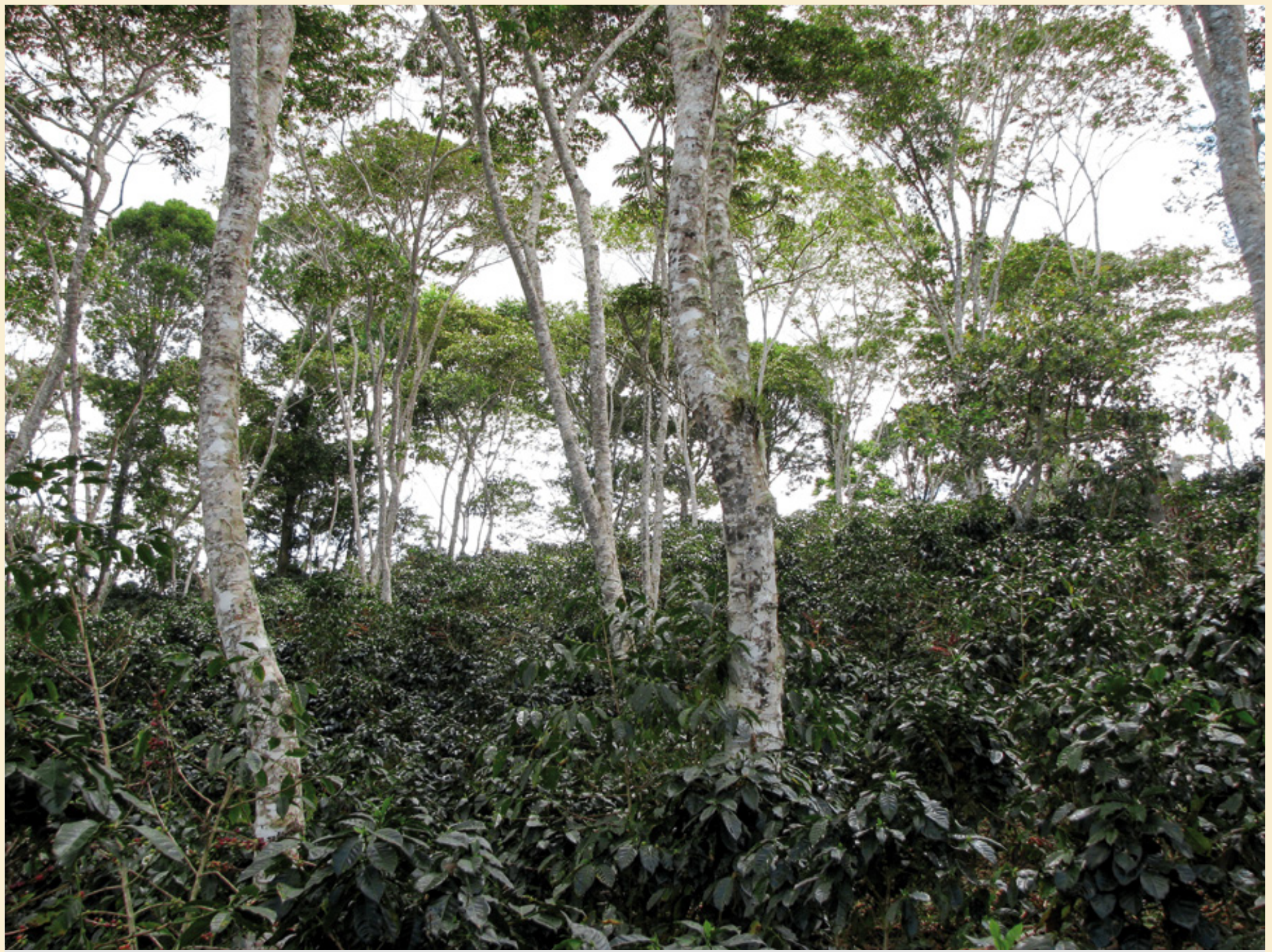

Photo 1.

Shaded part of Ave Fénix plantation is shaded dominantly by species of genus Inga spp.

Photo L. Ehrenbergerová. 


\section{RÉSUMÉ}

\section{IMPACT DE L'OMBRAGE SUR LE MICROCLIMAT D'UNE PLANTATION DE CAFÉ : ÉTUDE DE CAS EN AMAZONIE PÉRUVIENNE}

L'agroforesterie est considérée comme l'une des stratégies agricoles pouvant contribuer à l'adaptation des cultures au changement climatique. La présente étude de cas visait à comparer les conditions microclimatiques d'une parcelle de Coffea arabica cultivée sous ombrage, principalement Inga spp., et celles d'une parcelle de $C$. arabica menée en monoculture sans ombrage dans la même plantation de café, dans la région de Pasco au Pérou. La température et l'humidité de l'air, la température du sol et la disponibilité en eau du sol ont été mesurées pendant trois ans. Les résultats indiquent que l'ombrage des arbres réduit la température moyenne de l'air de $0,4 \pm 0,04^{\circ} \mathrm{C}$ et la température du sol de $1,7 \pm 0,3^{\circ} \mathrm{C}$, et augmente l'humidité de l'air de 3,9 0,4\% par rapport à la zone sans ombrage. Cependant, la moyenne mensuelle des températures de l'air dans la zone non ombragée, et même la température maximale, ne dépassent pas outre mesure la limite permettant la photosynthèse (seuil $34^{\circ} \mathrm{C}$ ). De plus, les températures minimales mensuelles diffèrent peu entre les zones ombragées et non ombragées, alors que la fluctuation des températures du sol est plus marquée dans la zone non ombragée. Un des principaux constats de cette étude concerne la sécheresse plus marquée des sols dans la zone ombragée, surtout au début et à la fin de la saison sèche. Ceci s'explique probablement par l'augmentation de la transpiration totale par celle des arbres d'ombrage. L'absorption d'eau plus importante en agroforesterie pourrait ainsi avoir un impact négatif sur la croissance des caféiers dans les situations où la disponibilité en eau est un facteur limitatif.

Mots-clés : agroforesterie, humidité de l'air, Coffea arabica, température du sol, disponibilité en eau du sol, Pérou, Amazonie.

\section{ABSTRACT}

\section{IMPACT OF TREE SHADING ON THE MICROCLIMATE OF A COFFEE PLANTATION: A CASE STUDY FROM THE PERUVIAN AMAZON}

Agroforestry is considered to be one of the agricultural strategies that could help to adapt crops to climate change. As a case study, we compared the microclimatic conditions at a location where Coffea arabica was shaded mainly by Inga spp. with the conditions in an unshaded $C$. arabica monoculture in the same coffee plantation in the Pasco region in Peru. Air temperature, air humidity, soil temperature and soil water availability were measured over three years. The results indicate that tree shading reduced the mean air temperature by $0.4 \pm 0.04{ }^{\circ} \mathrm{C}$ and soil temperature by $1.7 \pm 0.3{ }^{\circ} \mathrm{C}$, and increased air humidity by $3.9 \pm 0.4 \%$ compared to the unshaded area. However, the monthly average air temperature and even the monthly maximum in the unshaded area did not greatly exceed the limits for photosynthesis (upper limit $34^{\circ} \mathrm{C}$ ). Moreover, the minimum monthly air temperatures were similar in the shaded and unshaded areas. The soil temperatures did, however, fluctuate more markedly in the unshaded area. One of the main findings of this case study was that soil conditions were drier in the shaded area, especially at the beginning and end of the dry season. This was probably due to increased total transpiration resulting from that contributed by the shade trees. Thus, higher water uptake in agroforestry systems might have a negative impact on the growth of coffee plants where water availability is a limiting factor.

Keywords: agroforestry system, air humidity, Coffea arabica, soil temperature, soil water availability, Peru, Amazonia.

\section{RESUMEN}

\author{
IMPACTO DE LA SOMBRA EN \\ EL MICROCLIMA DE UNA PLANTACIÓN \\ DE CAFÉ: ESTUDIO DE CASO EN \\ LA AMAZONÍA PERUANA
}

La agroforestería está considerada como una de las estrategias agrícolas que puede contribuir a la adaptación de los cultivos al cambio climático. Este estudio de caso compara las condiciones microclimáticas de una parcela de Coffea arabica cultivada con sombra, principalmente de Inga spp., con las de una parcela con monocultivo de $C$. arabica sin sombra, ambas en la misma plantación de café en la región de Pasco en Perú. Durante tres años se efectuaron mediciones de la temperatura del aire, la humedad del aire, la temperatura del suelo y la disponibilidad de agua en el suelo. Los resultados indican que la sombra de los árboles reduce la temperatura media del aire de $0,4 \pm 0,04^{\circ} \mathrm{C}$ y la temperatura del suelo de $1,7 \pm 0,3^{\circ} \mathrm{C}$, y aumenta la humedad del aire de 3,9 $\pm 0,4 \%$ con respecto a la zona no sombreada. Sin embargo, la media mensual de las temperaturas del aire en la zona sin sombra, e incluso la temperatura máxima, no superan excesivamente el límite que posibilita la fotosíntesis $\left(34^{\circ} \mathrm{C}\right)$. Además, las temperaturas mínimas mensuales varían poco entre zonas con sombra y sin sombra, mientras que la fluctuación de las temperaturas del suelo fue más acusada en la zona sin sombra. Una de las observaciones más importantes de este estudio fue que las condiciones de suelo eran más secas en la zona sombreada, especialmente al principio y al final de la temporada seca. Probablemente esto se deba al aumento de la transpiración total que inducen los árboles de sombra. La mayor absorción de agua en los sistemas agroforestales podría afectar negativamente al crecimiento de las plantas de café en aquellas situaciones en las que la disponibilidad de agua sea una limitante.

Palabras clave: agroforestería, humedad del aire, Coffea arabica, temperatura del suelo, disponibilidad de agua en el suelo, Perú, Amazonía. 


\section{Introduction}

There is substantial concern about the impacts of climate change on agricultural production at the worldwide scale (Fischer et al., 2005). A large fraction of the world's food is grown in the tropics, and climate change is expected to modify the frequency, intensity and duration of climate extreme events there (Slingo et al., 2005; IPCC, 2007). Arabica coffee, Coffea arabica L., the most widespread species of the genus Coffee, is known to be climate-sensitive, with existing plantations expected to largely be negatively impacted by climate change (Davis et al., 2012). In particular, in South America, close to the equator, although coffee plantations at higher elevations could benefit from climate change, those at low altitudes and higher latitudes coffee plantations will lose suitability (Bunn et al., 2015; Ovalle-Rivera, 2015).

Indeed, South America has been forecasted to experience major climatic changes and ecological consequences, including temperature increases and associated soil water decreases projected to yield gradual replacement of tropical forest by savanna in eastern Amazonia, by mid-century (Solomon et al., 2007). Moreover, the drought in Amazonia in 2005 has already provided a good example of climate extremes at the seasonal time scale (Marengo, 2010). Agroforestry should be considered as a major climate-smart agriculture option as it combines sustainable production with adaptation and mitigation of climate change (Vaast et al., 2016). Moreover, it is an economically feasible way to protect crop plants from extremes in microclimatic conditions (Lin, 2007).

Arabica coffee is cultivated in using various management schemes, from the heavy shade of companion trees, constituting a typical agroforestry system, to monoculture (Siles et al., 2010a). In fact, C. arabica is shade-adapted, with leaves that can maintain a high photosynthetic performance under low light availability (Franck and Vaast, 2009), making it well-suited to heavily shaded systems. Agroforestry provides additional benefits not yielded by coffee plantations grown in full sun, including serving as a refuge for forest biota (Moguel and Toledo, 1999), reducing pressure for further forest conversion to agriculture (Noponen et al., 2013), serving as a source of fuel-wood and construction material (Rice, 2008), stabilizing microclimatic conditions (Lin, 2007; Siles et al., 2010a), and protecting the soil (Siebert, 2002). On the other hand, shade trees may compete with coffee for resources such as light, water and soil nutrients (Laycock and Wood, 1963; Siles et al., 2010a). Additionally, the presence of shade trees reduces air movement and increases humidity, which may favour fungal diseases (Smith, 1981).

The optimal air temperature range for Arabica coffee growth is $18-21^{\circ} \mathrm{C}$ (Alegre, 1959), and for its photosynthesis it is $18-24^{\circ} \mathrm{C}$. For adequate root development, $24-27^{\circ} \mathrm{C}$ seems to be the best soil temperature range (IBC, 1986). At air temperatures above $24^{\circ} \mathrm{C}$, the net photosynthesis decreases, approaching zero at $34{ }^{\circ} \mathrm{C}$ (Nunes et al., 1968). Mes (1957) observed deficient floral development and a large number of aborted flowers caused by high air temperatures ( $30^{\circ} \mathrm{C}$ during the day, and $24^{\circ} \mathrm{C}$ during the night). Increasing night-time temperature was the most significant climatic variable responsible for diminishing Coffea arabica yields between 1961 and 2012 in the northern Tanzanian highlands. Projecting based on this suggests that every $1^{\circ} \mathrm{C}$ rise in night-time temperature above the optimal range will result in annual yield losses of $137 \pm 16.87 \mathrm{~kg} / \mathrm{ha}$ (Craparo et al., 2015).

However, impacts of increased temperature due to elevated atmospheric $\mathrm{CO}_{2}$ are not likely to be universally negative. In particular, elevated $\mathrm{CO}_{2}$ has been shown to mitigate the impact of heat on coffee physiology (Rodrigues et al., 2016). Also, low temperatures might cause decreased growth and development in Coffea arabica (Garab, 1998), so that as mentioned above, in cooler, marginal coffee-growing areas, increased temperatures might be beneficial to the crop. Finally, effects of changing climate on coffee crops should take into account not only temperature changes, but shifts in precipitation because, for example, rainfall on the flowering day has been found to have a negative influence on coffee production too (Boreux, 2016).

Shade cover affects microclimatic fluctuations more dramatically than it affects mean values of climatic and soil moisture measurements (Lin, 2007). Compared to coffee monoculture, under Inga spp. trees (one of the main species used for shade in South American agroforestry systems), maximum temperature of coffee leaves has been shown to be reduced by up to $5{ }^{\circ} \mathrm{C}$ and minimum air temperature at night increased by up to $0.5^{\circ} \mathrm{C}$, with these shade trees thus buffering against large diurnal variations in air temperature that are detrimental to coffee physiology (Siles et al., 2010a).

The presence of shade cover in agroforestry systems has the potential to reduce soil evaporation and coffee transpiration (Lin, 2010). Lin (2010) found that the topsoil $(0-30 \mathrm{~cm})$ was drier at the non-shaded area and at depths of $100-200 \mathrm{~cm}$, but also found that, overall, soil water was more available at the non-shaded area. Cannavo et al. (2011), comparing two adjacent plots, one a coffee-Inga densiflora agroforestry system and the other a coffee monoculture, found reduced coffee transpiration and soil evaporation, as Lin (2010) had predicted. However, Cannavo et al. (2011) also detected higher total (i.e., combined effects of coffee and shade trees) transpiration and higher rainfall interception in the agroforestry system in comparison to the coffee monoculture. Higher actual evapotranspiration in the agroforestry system also resulted in lower drainage than in the monoculture (Siles et al., 2010b; Cannavo et al., 2011). The authors also showed that runoff was lower and water infiltration was higher in the shaded plot. The issue of rainfall interception was further studied by Vaast et al. (2014), who found that a canopy of coffee and shade trees to intercept $15-25 \%$ of the rainfall, with coffee trees intercepting the largest part of the rainfall (9-21\%).

Although shade cover can be beneficial for coffee growth and production in suboptimal climatic conditions (Vaast et al., 2008), it is important to regulate the quantity of shade, because too much of it can result in a very humid microclimate conducive to higher incidence of fungal diseases such as leaf rust (caused by Hemileia vastatrix) (Avelino et al., 2007) and American leaf spot (caused by Mycena citricolor) (Wintgens, 2004). 


\section{Methods}

In the face of increasing climate instability, it is necessary to find sustainable and financially viable coping strategies for small farmers who have limited access to technological improvements (Lin, 2007). Both from the crop-production and ecological points of view, knowledge of the microclimatic changes in shaded systems through the crop cycle, and in different periods of the year is needed, in order to establish agronomically and ecologically sustainable practices (Morais et al., 2006). In the present case study, we aimed to assess: (1) the effects of shade on air temperatures and humidity in a coffee plantation; and (2) the ability of shade trees to affect soil water availability at different soil depths and through the course of the year. For this study, the Ave Fénix coffee plantation in the town of Villa Rica, Peru was chosen. This plantation is cultivated partly as an agroforestry system shaded by Inga spp. (photo 1) and partly without shade, allowing us to isolate the effects of shading.

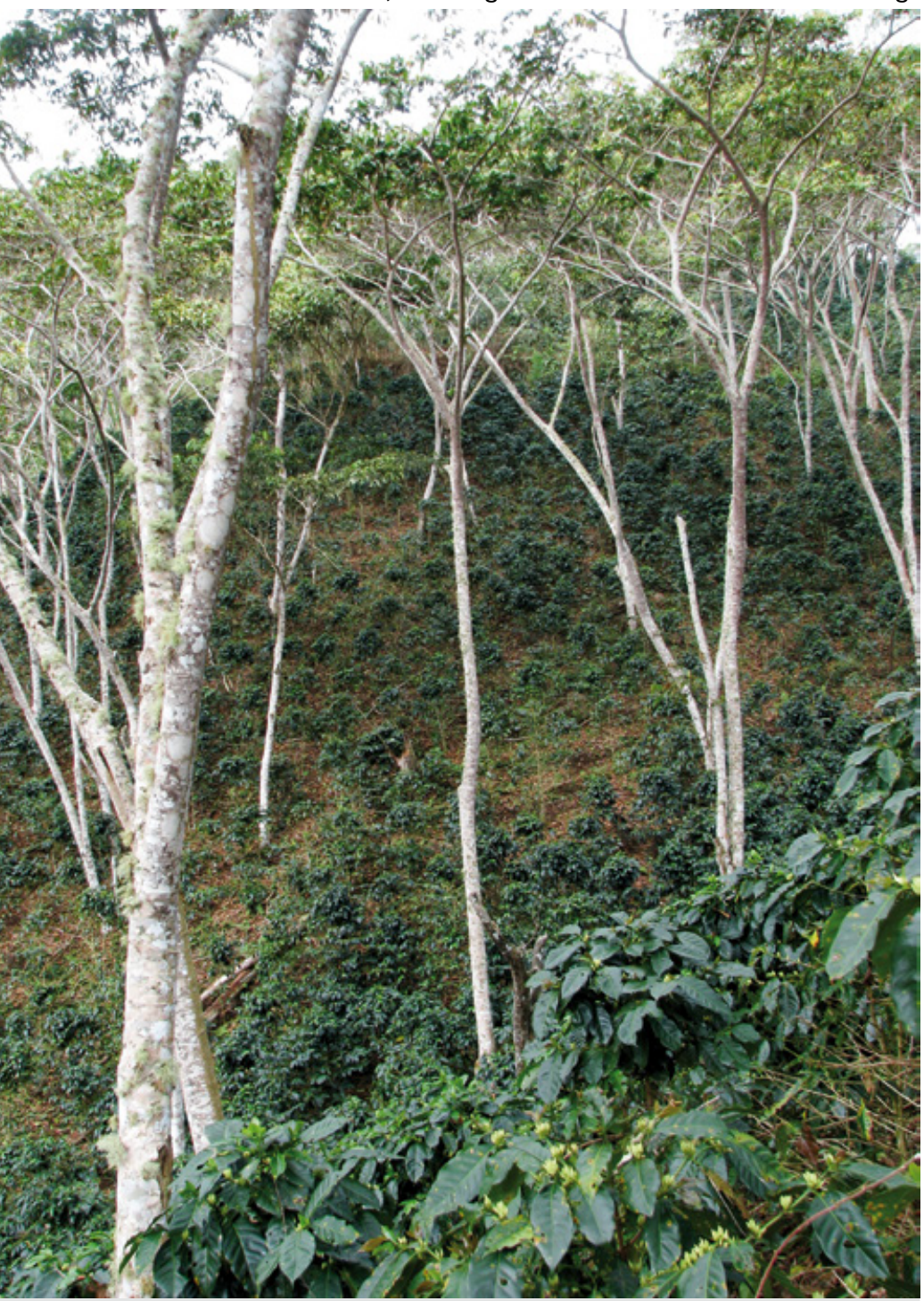

Photo 2.

Management and structure of Ave Fénix is typical for the coffee plantations in Villa Rica district. Photo L. Ehrenbergerová.
This study was conducted near the town of Villa Rica, in the Pasco region, Peru. Villa Rica is the Peruvian centre of coffee cultivation, and is situated at an altitude of $1,500 \mathrm{~m}$ a.s.l. The average annual rainfall in this tropical humid mountain forest zone is $1,590 \mathrm{~mm}$, and the average annual temperature is $17.8^{\circ} \mathrm{C}$ (Ponce, 2008). Villa Rica thus belongs to the tropical rain forest zone using Holdridge's classification (Khatun et al., 2013). According to the Food and Agriculture Organization (FAO), soils in this region are dystric cambisols (Michéli et al., 2006). This soil type is commonly used for coffee plantations. The main economic activity is agriculture, and the landscape surrounding Villa Rica is characterised by shaded coffee plantations with some cattle farming.

Ave Fénix plantation (10³6'37" S; 7513'25" W) was chosen for this study both because it allows comparison of shaded and unshaded coffee cultivation and because its management and plantation structure are typical of the region (photo 2), making it especially useful for a case study. The plantation is characterised by a broken topography, with an average slope of $18.2^{\circ}$. In the first $30 \mathrm{~cm}$, the soil texture is classified as clay loam, with the soil reaction extremely acid $\left(\mathrm{pH}_{\mathrm{KCl}} 3.8\right)$ and the amount of organic carbon very high (2\%) (Ehrenbergerová et al., 2016). We found four coffee varieties on the plantation: Typica, Catimor, Caturra and Catuai. The plantation is divided into two areas: a shaded area (7.37 ha) and a non-shaded area $(0.98 \mathrm{ha})$. The dominant shade tree genus in the shaded area is Inga spp. (Inga adenophylla Pittier, I. densiflora Bentham, I. edulis C. Marius, I. feuillei DC., I. velutina Willdenow), but other tree species are also present. Indeed, in the shaded area, 54 shade tree species were identified, with the tree density being 176 trees/ha and mean tree height $13.7 \pm 2.4 \mathrm{~m}$.

We chose two circular areas with perimeters of $30 \mathrm{~m}$, and a sensor set was placed in the centre of each. In the shaded area, the sensor set was located under shade tree cover, whereas the non-shaded area entirely lacked trees (figure 1). The locations of the sensor sets had the same slope inclination and aspect. The sensor set configuration was the same at both areas, with each set containing one sensor for air temperature, one for air humidity, one for soil temperature and two gypsum block devices for assessing soil water availability (figure 1). The air temperature and air humidity at a height of $2 \mathrm{~m}$ were measured using a Minikin TH (EMS, Brno, Czech Republic) with sensor accuracy $\pm 0.2{ }^{\circ} \mathrm{C}$ and $\pm 2 \%$ (photo 3). Soil temperature at the depth of $10 \mathrm{~cm}$ was measured by MicroLog T3 (EMS, Brno, Czech Republic) with accuracy $\pm 0.2^{\circ} \mathrm{C}$. The gypsum block devices (GB2, Delmhorst Inc., USA) were connected to a data logger (MicroLog SP, EMS, Brno, Czech Republic), with accuracy better than $2 \%$, and were buried at depths of 10 and $40 \mathrm{~cm}$ within the root zone of coffee plants. All microclimatic data were recorded in the data-loggers memory every hour, and microclimatic measurements were conducted from February 2011 to January 2014. Soil water availability data were further interpreted according to generally accepted hydro-limit values (e.g., Čermák and Prax, 2001). Therefore, the values 0.1-4 bar represent "easily available water" in soil, and values between 4.1-10 bars represent "reduced soil water availability “. The values higher than 10 bars characterise "hardly available water" in soil. 


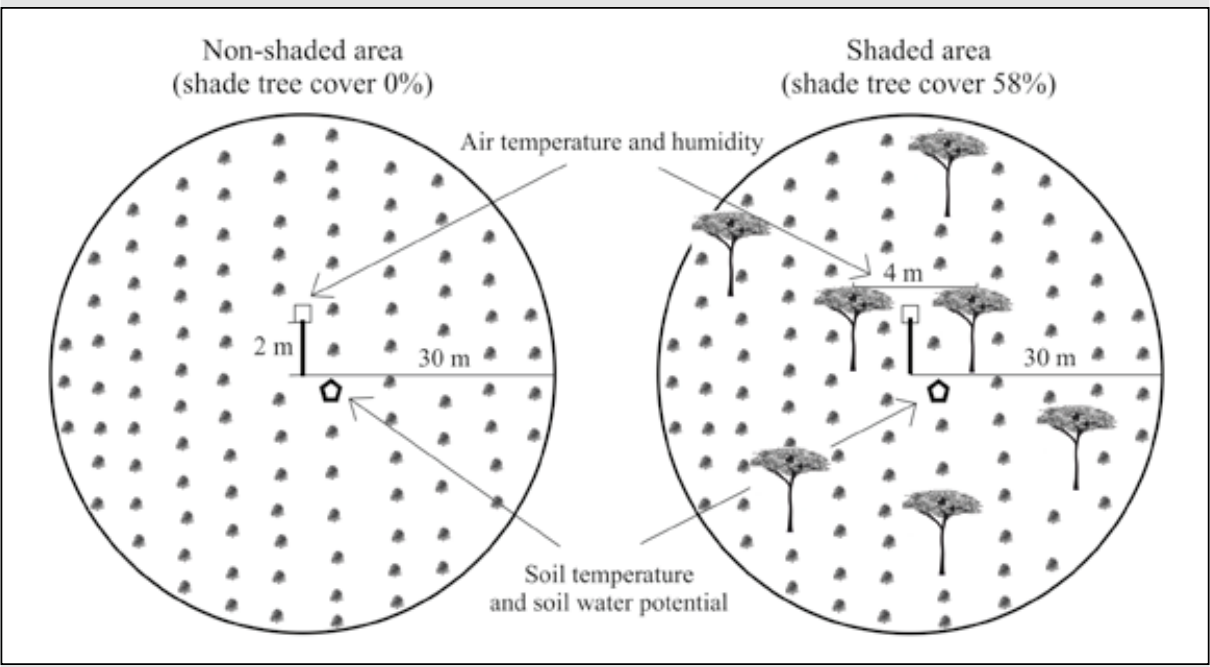

Figure 1.

Positions of sensor sets in the non-shaded and shaded areas.

\section{Results}

\section{Air Temperature}

The average annual air temperature at the shaded area was $18.3 \pm 0.3{ }^{\circ} \mathrm{C}$ and at the non-shaded area it was $18.8 \pm 0.3^{\circ} \mathrm{C}$. At both areas, the coldest month during the study period was July while the warmest was November (figure 2). The monthly mean air temperatures during the whole experimental period were higher at the non-shaded area by $0.4 \pm 0.04{ }^{\circ} \mathrm{C}$. The climatic data was measured for 26,282 hours. Within this period, the air temperature was non-optimal for coffee (higher than $21^{\circ} \mathrm{C}$ ) at the shaded area for 4,834 hours and at the non-shaded area for 6,186 hours. The monthly average of daily maximum air temperature was lower at the shaded area by $2.09 \pm 2.68{ }^{\circ} \mathrm{C}$ during the whole studied period, and the monthly average of daily minimum air temperature was almost the same at both studied areas (figure 1).

The comparison of daily microclimate fluctuations for wet and dry months (January and September) of 2012 is shown in figure 3. In September 2012 (dry season), the maximum temperature was $29.5^{\circ} \mathrm{C}$ at the shaded area and $31{ }^{\circ} \mathrm{C}$ at the non-shaded area, whereas in January 2012 (wet season) it was $28.7^{\circ} \mathrm{C}$ at the shaded area and $28.8^{\circ} \mathrm{C}$ at the non-shaded area. The shaded area exceeded the coffee shrub optimal temperature of $21^{\circ} \mathrm{C}$ in the wet season between 12 a.m. (or 11 a.m. in the dry season) and 6 p.m., whereas the non-shaded area exceeded this optimum between 11 a.m. (or 10 a.m. for the dry season) and 6 p.m., thus for one hour more than the shaded area. The difference between hourly average maximum and minimum air temperatures was $6.6 \pm 0.5^{\circ} \mathrm{C}$ at the shaded area and $7.7 \pm 0.5^{\circ} \mathrm{C}$ at the non-shaded area in the wet season, and $9.3 \pm 0.8^{\circ} \mathrm{C}$ at the shaded area and $10.8 \pm 0.9^{\circ} \mathrm{C}$ at the non-shaded area in the dry season.
The average minimum daily air temperatures were almost the same during the wet January 2012: $16.3^{\circ} \mathrm{C}$ - shaded and $16.4{ }^{\circ} \mathrm{C}$ - non-shaded area) and dry months (September 2012: $14.9{ }^{\circ} \mathrm{C}$ - shaded and $14.8^{\circ} \mathrm{C}$ non-shaded area) and was a little less than coffee's optimal range $18-21^{\circ} \mathrm{C}$ (Alegre, 1959). However, the average maximum daily air temperatures were beyond coffee's optimal range (Alegre, 1959): in January 2012 they were $22.9^{\circ} \mathrm{C}$ and $24.1^{\circ} \mathrm{C}$ they were and in September $201224.2^{\circ} \mathrm{C}$ and $25.5^{\circ} \mathrm{C}$ at the shaded and non-shaded areas, respectively (figure 3).

\section{Air humidity}

The lowest humidity for both studied plantations was in September and the highest from December to March (figure 2). During the whole measurement period, the air humidity was higher by $3.9 \pm 0.4 \%$ at the shaded area than the non-shaded area (figure 2). The average annual air humidity at the shaded area over the three measured years was $93.7 \pm 1.4 \%$ and at the non-shaded area it was $89.8 \pm 1.8 \%$. The hourly mean air humidity was also higher at the shaded area for both wet and dry months. As in the case of air temperature, for air humidity the daily fluctuations were smaller at the shaded area (figure 3). There was no difference in the monthly averages of daily maximum air humidity between the studied areas, but the monthly average of daily minimum air humidity was higher at the shaded area by $8.16 \pm 0.86 \%$ (figure 1 ).

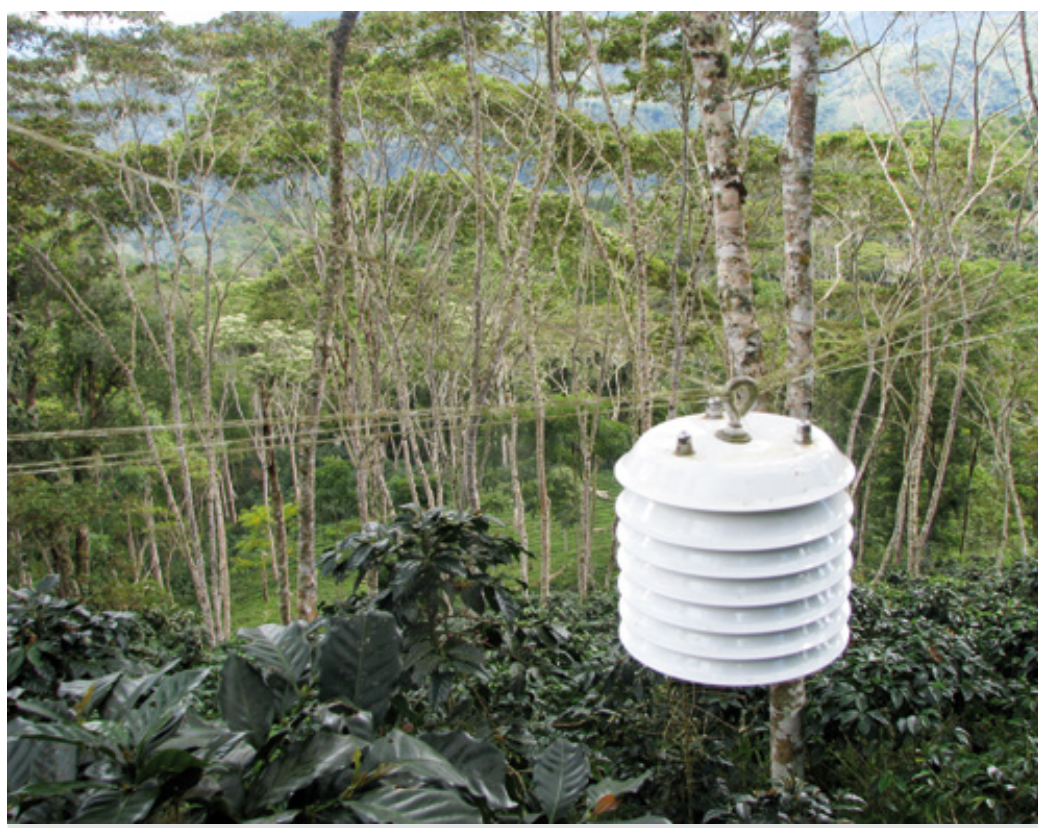

Photo 3.

Minikin TH used for air temperature and air humidity measurement; these units were installed at a height of $2 \mathrm{~m}$. Photo L. Ehrenbergerová. 

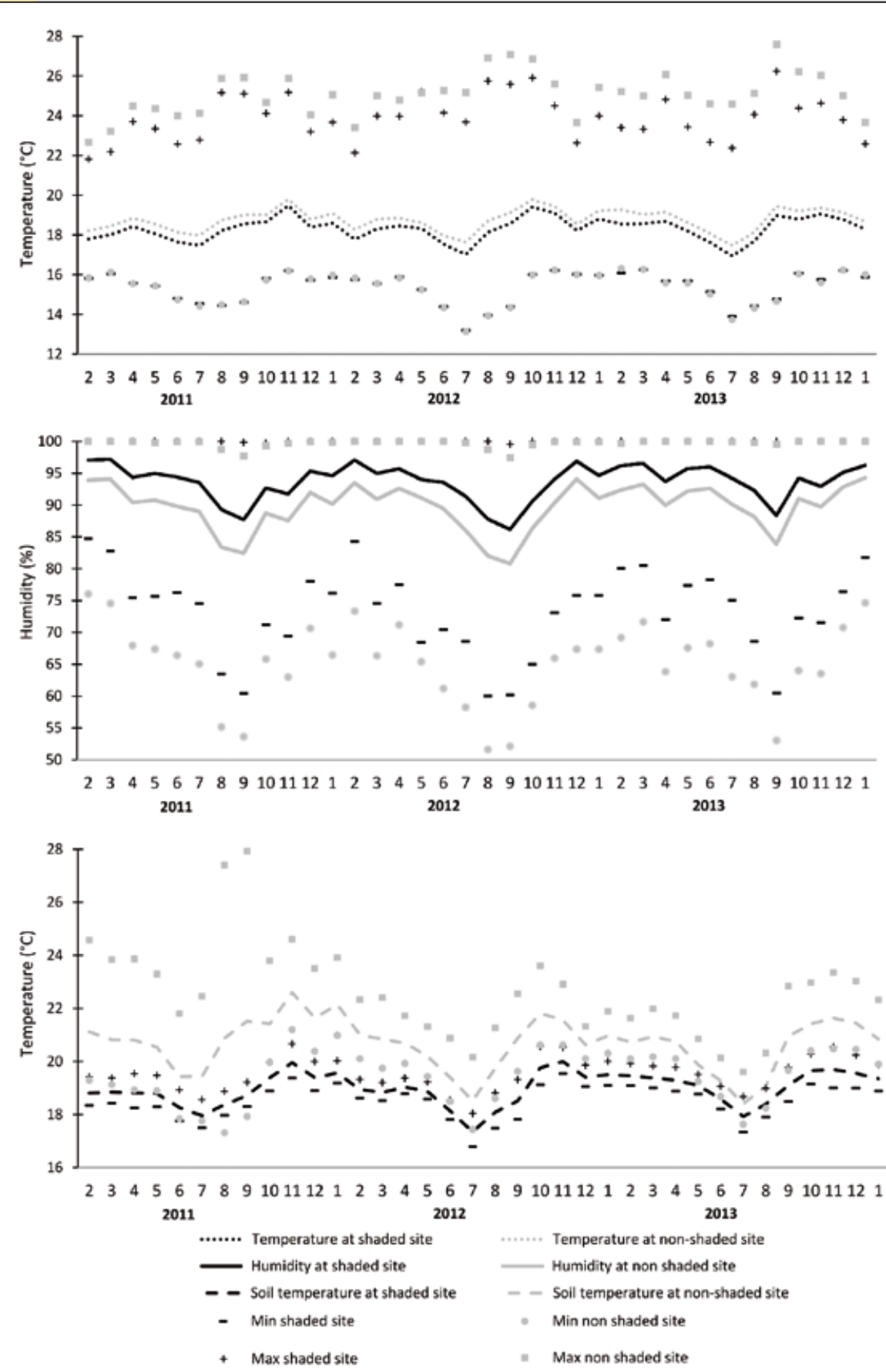

Figure 2.

Mean monthly courses of air and soil temperatures and humidity for years 2011-2013 at the shaded and non-shaded areas.

\section{Soil temperature}

The average monthly soil temperature for years 2011 2013 was $19 \pm 0.3^{\circ} \mathrm{C}$ at the shaded area and $20.7 \pm 0.5^{\circ} \mathrm{C}$ at the non-shaded area. The lowest soil temperature at both areas was in July and the highest was between October and November (figure 2). The average monthly soil temperatures were lower at the shaded area by $1.7 \pm 0.3^{\circ} \mathrm{C}$ than the non-shaded area. The monthly average of daily maximum soil temperature was lower by $3.07 \pm 0.83{ }^{\circ} \mathrm{C}$ at the shaded area, and also the minimum was lower at the shaded area by $0.93 \pm 0.27^{\circ} \mathrm{C}$.

The non-shaded area had higher soil temperatures during the day and also during the night in both the wet (difference $2.6 \pm 0.4^{\circ} \mathrm{C}$ ) and the dry (difference $2.3 \pm 0.3^{\circ} \mathrm{C}$ ) months. The average difference between daily maximum and minimum soil temperatures was $0.7 \pm 0.2{ }^{\circ} \mathrm{C}$ at the shaded area and $2.7 \pm 0.7{ }^{\circ} \mathrm{C}$ at the non-shaded area in the wet season and $2.5 \pm 0.4{ }^{\circ} \mathrm{C}$ at the shaded area and $1.2 \pm 0.2{ }^{\circ} \mathrm{C}$ at the non-shaded area in the dry season. The average hourly soil temperature fluctuation was almost unnoticeable at the shaded area but pronounced at the non-shaded area during both wet and dry months (figure 3). Maximum ambient midday soil temperatures at $10 \mathrm{~cm}$ depth were lower in the shaded location.

\section{Water availability}

Table I and figure 4 indicate drier soil conditions at the shaded area than the nonshaded area during the dry season, whereas during the wet season the water was "easily available" at both areas. The dry season started in June and finished in October in all study years. The period characterized by "hardly available water" started earlier and lasted longer at the shaded area (table I., figure 4). However, the relative amounts of soil moisture at the two areas differed at the different measurement depths: at the depth of $10 \mathrm{~cm}$, the non-shaded area had more days with dry soils, whereas at the depth of $40 \mathrm{~cm}$ the shaded area had dry conditions for more days (table I). Nevertheless, the number of days characterised as having "hardly available water" was higher at shaded site.

\section{Discussion}

Visible symptoms of damage of coffee can be caused by overheating (Willey, 1975). Although we found that the area without the protection of shade trees would get warmer, the differences in air temperatures in shaded and non-shaded areas were small, which is in accordance with the findings of Morais et al. (2006). In our case study, at the non-shaded area, the temperature was higher than optimal for coffee growth $\left(21^{\circ} \mathrm{C}\right)$ (Alegre, 1959) for a longer time, but it (even the monthly maximum temperatures) did not exceed the limit $\left(30^{\circ} \mathrm{C}\right.$ in the day, and $24^{\circ} \mathrm{C}$ in the night) above which Mes (1957) observed deficient floral development and a large number of aborted flowers. 


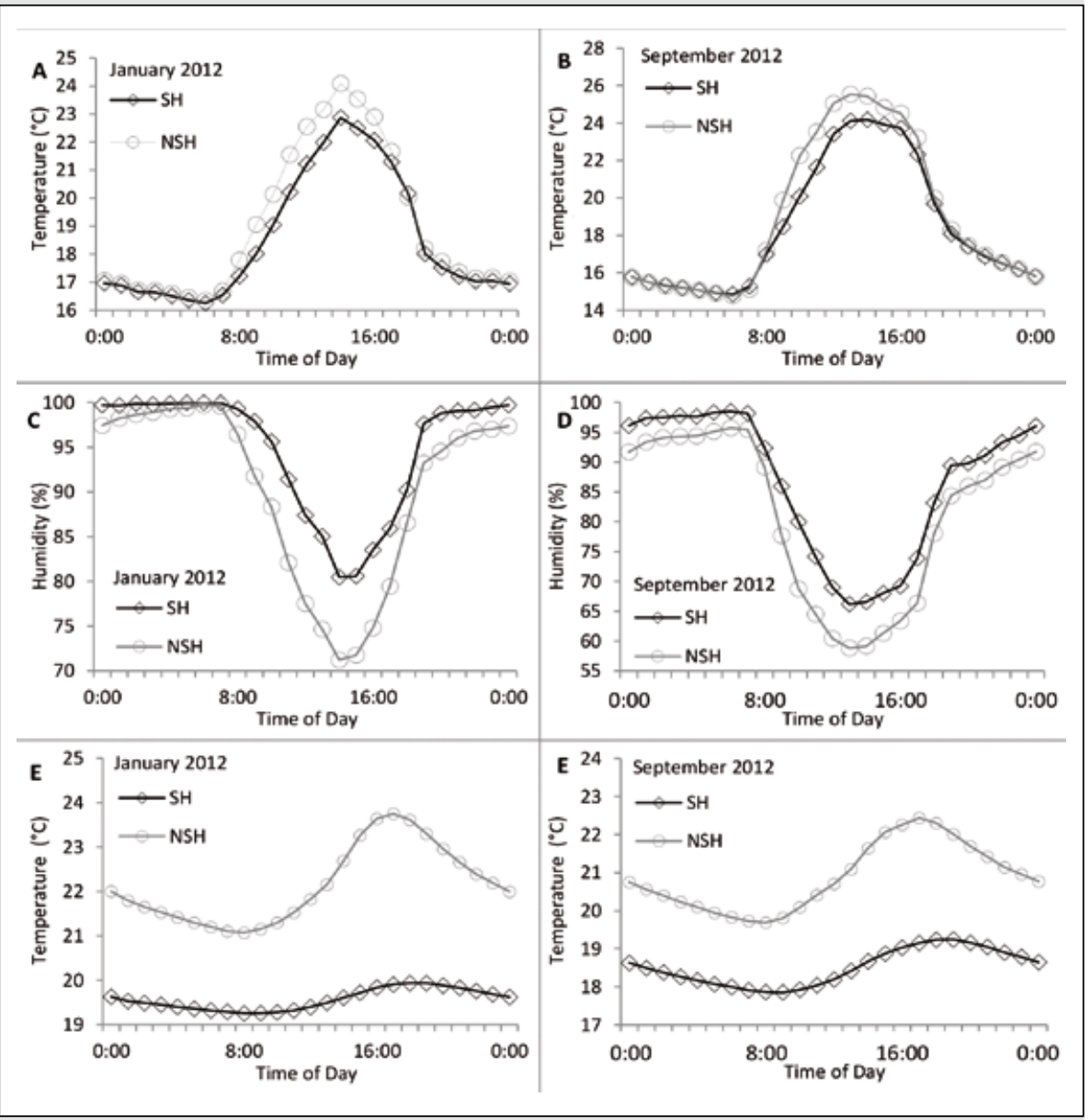

Figure3.

Area averages of air temperature (A, B), air humidity $(C, D)$ and soil temperature $(E, F)$ by time of day, separated into wet (January 2012) and dry (September 2012) months. SH - shaded area, $\mathrm{NSH}$ - non-shaded area.

Although our finding of higher maximum monthly temperatures (recorded in daytime) at the non-shaded area was consistent with previous studies (Barradas and Fanjul, 1986; Lin, 2007; Siles et al., 2010a), our finding of the same minimum monthly temperatures (recorded at night) at both study areas is in contrast to these other studies, which found that low-shaded or non-shaded areas had lower temperatures during the night. Our contrasting results are of particular interest because increasing night-time temperature can cause diminished Coffea arabica yield and it has been suggested that shade trees can mitigate this climate change effect (Craparo et al., 2015). Our study suggests that such mitigation would not universally occur. However, our results are consistent with those of Lin (2007) in showing daily air temperature fluctuations to increase significantly with decreasing shade cover. In our case study, the difference between daily temperature fluctuations was substantial in the dry season, when the temperatures during the day exceeded the optimal limit for coffee photosynthesis $\left(24^{\circ} \mathrm{C}\right)$ (Nunes et al., 1968) (figure 3).
As in the case of air temperature, for air humidity the daily fluctuations were smaller at the shaded area (figure 3), corresponding with the findings of Lin (2007). The higher humidity at the shaded area was in accordance with Barradas and Fanjul (1986), who explained it by higher output of water vapour produced by a much higher transpiration rate of canopy trees pumping water from lower soil layers. Additionally, shade of up to $55 \%$ is beneficial for coffee leaf photosynthesis as it maintains greater coffee net photosynthesis relative to plants in full sun via a significant attenuation of stomatal stress (Franck and Vaast, 2009).

Higher humidity is favourable for coffee shrubs during the dry season, but it can be problematic during the wet season because of increased risk to the coffee shrubs from fungal diseases (Avellino et al., 2007; Smith, 1981). For example, coffee leaf rust (caused by Hemileia vastarix) generally develops during the rainy season (Avelino et al., 1991), but the lack of rain does not seem to be a significant limiting factor for developing this disease. Other sources of free water, such as dew, can facilitate the germination of spores during the absence of rain (Muller, 1975). Similarly, American leaf spot (caused by Mycena citricolor) develops in very damp conditions, and high humidity can cause epidemics of this disease (Wintgens, 2004).

\begin{tabular}{|c|c|c|c|c|}
\hline \multicolumn{5}{|c|}{$\begin{array}{l}\text { Table I. } \\
\text { Numbers of days classified according to their daily average } \\
\text { soil water availability values in three soil water availability } \\
\text { categories ("easily available water" = } 0-4 \text { bars, "reduced soil } \\
\text { water availability" = } 4.1-10 \text { bars, "hardly available water" } \\
>10 \text { bars) for two SWP measurements depths, } 10 \mathrm{~cm} \text { and } 40 \mathrm{~cm} \text {. }\end{array}$} \\
\hline \multirow[t]{2}{*}{ SWP (bar) } & \multicolumn{2}{|c|}{ shaded } & \multicolumn{2}{|c|}{ non-shaded } \\
\hline & $10 \mathrm{~cm}$ & $40 \mathrm{~cm}$ & $10 \mathrm{~cm}$ & $40 \mathrm{~cm}$ \\
\hline $0-4$ & 898 & 869 & 976 & 1,003 \\
\hline $4.1-10.0$ & 25 & 31 & 22 & 7 \\
\hline$>10$ & 166 & 172 & 74 & 57 \\
\hline
\end{tabular}




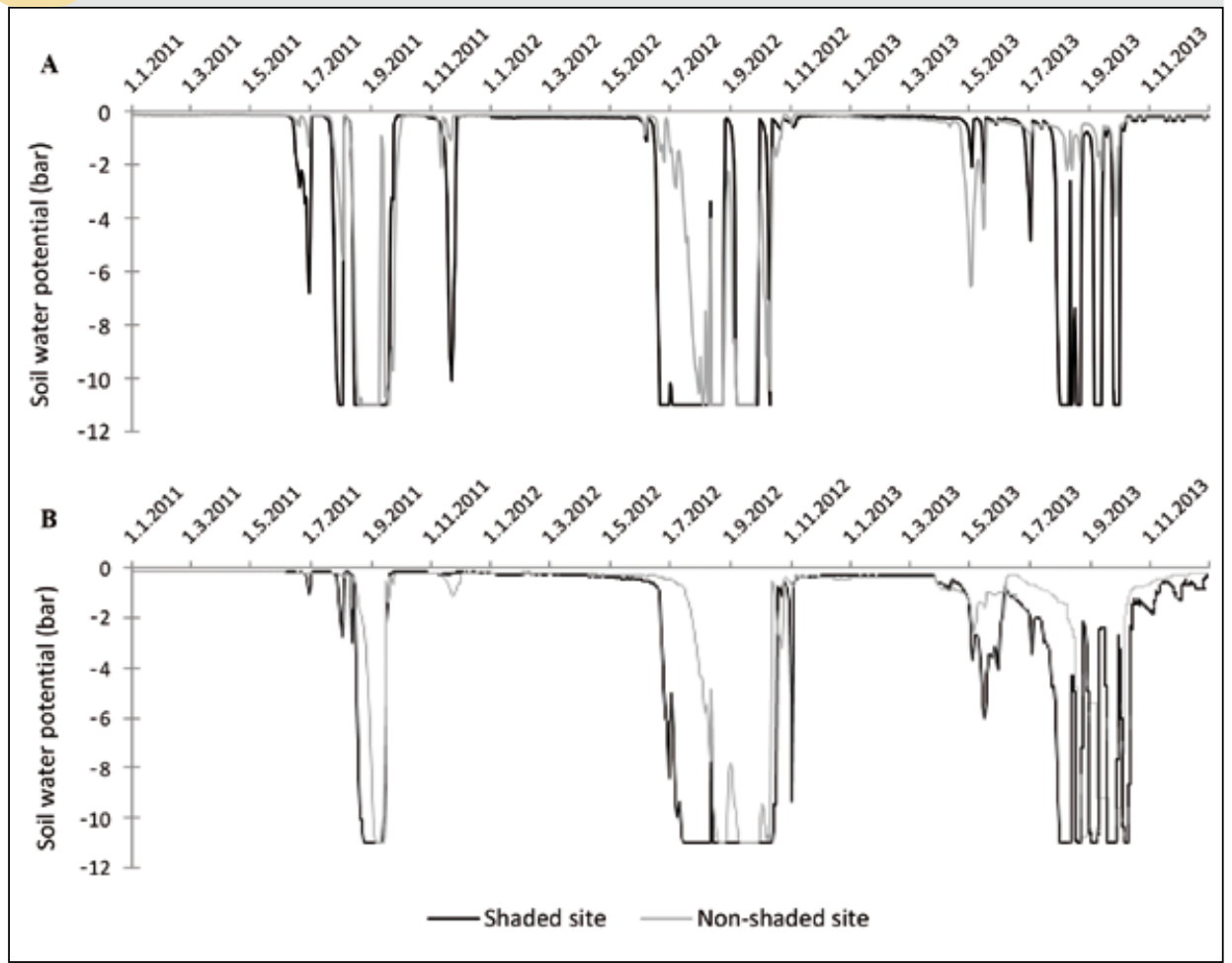

Figure 4.

Soil water availability curves (bar) at shaded and non-shaded areas at depths (A) $10 \mathrm{~cm}$ and (B) $40 \mathrm{~cm}$. lower in a coffee agroforestry system than in unshaded coffee. Also consistent with our results, Harmand et al. (2007) reported that at the end of the dry season the soil water content of the $0-120 \mathrm{~cm}$ layer was higher in an unshaded coffee plantation than in a shaded area. The reason for this could be that shade tree roots exhausted a significant part of the soil water during the dry season (Laycock and Wood, 1963; Siles et al., 2010a). Commonly, such trees transpire daily sums of 30 to 600 litres of water (Čermák et al., 2015). In fact, such water use explains why localities often become wetter after deforestation (Locatelli and Vignola, 2009). Van Kanten and Vaast (2006) found that agroforestry systems used more water than non-shaded areas, but this did not result in any competition between coffee and shade trees in the wet conditions of southern Costa Rica.

On the other hand, Morais et al. (2006) and Suárez de Castro et al. (1961) have reported soil moisture was higher in shaded than unshaded areas. This finding has been explained by the shade tree's litter layer reducing evaporative loss of soil water along with the sha-

The average monthly soil temperatures were lower at the shaded area than the non-shaded area (figure 2), which is in agreement with the results of other studies (Morais et al., 2006; Barradas and Fanjul, 1986). Our results are consistent with the fact that soil stabilizes the local thermal balance, absorbing a considerable quantity of heat during the day and returning it to the atmosphere at night. In a vegetated area, this stabilization is more efficient, with less thermal oscillation, because during the day the vegetation protects the soil surface against direct radiation that causes excessive heating, and during the night it minimizes thermal radiation loss (Rich et al., 1993). These dynamics would explain our results showing greater temperature fluctuation in the soil lacking shade cover. However, low soil temperatures affect root absorption more than high temperatures (IBC, 1986). Thus, at our non-shaded area, the soil temperatures were in the optimal soil temperature range $\left(17-24^{\circ} \mathrm{C}\right)$ for coffee roots (IBC, 1986) for a longer time than they were at the shaded area.

The length of the dry season appears to be far more important than the annual volume of rainfall, and water competition between coffee plants and shade trees is clearly possible in the case of prolonged dry seasons (Cannavo et al., 2011). In our study, the water availability always decreased earlier with the period of severe depletion (i.e., "hardly available water") lasting longer at the shaded area. Padovan et al. (2015) had similar results showing that after a severe dry period volumetric water and water uptake were ding decreasing the energy available for evaporation (Beer, 1992). Another possible explanation was that the shade trees increased moisture input through horizontal interception of mist or clouds (Willey, 1975).

In our study, although the amount of days characterised by severe dryness (i.e., "hardly available water") was higher at the shaded site, particular measures of soil moisture availability showed differing relative results depending upon the depth at which it was measured. Thus, the soil at the depth of $10 \mathrm{~cm}$ drier for more days in the non-shaded area, but the soil at $40 \mathrm{~cm}$ was drier for more days at the shaded area (table I). These results are consistent with those of Lin (2010) and Cannavo et al. (2011), who found the topsoil $(0-30 \mathrm{~cm})$ to be drier at the non-shaded area and on the contrary higher depths soil water was more available at the non-shaded area. The higher relative availability at nonshaded areas is likely due to water uptake by shade trees, as discussed above. The effect of shade tree mediation of soil moisture availability on coffee production should likely depend upon precipitation amount and its timing. For example, in the study of Cannavo et al. (2011), coffee fruit development took place during the wet season when soil was at field capacity due to heavy and frequent rainfall, and thus would likely not have a strong effect. Similarly, water supply is not likely to be a limiting factor in other coffee-producing regions such as in Costa Rica (Carr, 2001), where rainfall coincides with fruit development. 


\section{Conclusions}

We detected both positive and negative effects of shaded Inga spp. trees on microclimate conditions of coffee plantation. Positive effects included the reduction of air as well as soil temperature fluctuations. One negative effect could be the increase in number days with lower soil water availability in the shaded area. The monthly average air temperature was detected to be almost the same in both studied areas. The monthly maximum temperature was higher in the non-shaded area, but even there, it would not pose a serious problem for photosynthesis. A particularly interesting finding is the absence of a difference in minimum monthly air temperatures between the studied areas. Additionally, the shaded area showed higher air humidity than non-shaded area, which could be problematic if it promotes fungal diseases. However, the most important results were from soil measurements, which showed greater duration of severely dry conditions in the shaded area. Such lower soil water availability could pose problems for coffee production in drier climates. Therefore, the water conditions at each plantation should be evaluated and the appropriate shade tree species and densities used based on their water requirements. Moreover, the high consumption of water by shade trees in coffee plantations can be advantageous on sites with excess water. The results of this case study can be used in broader investigations aimed at generalizing the effects of shade trees on coffee plantation microclimate properties worldwide as this topic is becoming increasingly important with ongoing climate change

\section{Acknowledgments}

The authors wish to thank: the members of Marín family for their help and for letting us conduct this study on their plantation; Jorge Mattos Olavarria, general manager of MapGeosolution for financial support; POPRAR project CZ.1.07/2.2.00/28.0303, for financial support; and also Jonathan Rosenthal for English correction.

\section{References}

Alegre C., 1959. Climats et caféiers d'Arabie. Agronomie Tropicale, 14: 23-58.

Avelino J., Muller R. A., Cilas C., Velasco Pascual H., 1991. Development and behavior of coffee orange rust (Hemileia vastatrix Berk. and $\mathrm{Br}$.) in plantations undergoing modernization, planted with dwarf varieties in South-East Mexico. Café Cacao Thé, 35 (1): 21-37. Avelino J., Cabut S., Barboza B., Barquero M., Alfaro R., Esquivel C., et al., 2007. Topography and crop management are key factors for the development of American leaf spot epidemics on coffee in Costa Rica. Phytopathology, 97: 1532-1542.

Barradas V. L., Fanjul L., 1986. Microclimatic characterization of shaded and open-grown coffee (Coffea arabica L.) plantations in Mexico. Agricultural and Forest Meteorology, 38: 101-112.

Beer J. W., 1992. Production and competitive effects of the shade trees Cordia alliodora and Erythrina poeppigiana in an agroforestry system with Coffea arabica. United Kingdom, Ph. D., University of Oxford, $230 \mathrm{p}$.
Boreux J., Vaast P., Madappa L. P., Cheppudira K. G., Garcia C., Ghazoul J., 2016. Agroforestry coffee production increased by native shade trees, irrigation, and liming. Agronomy for Sustainable Development, 36 (3): 1-9.

Bunn C., Läderach P., Rivera O. O., Kirschke D., 2015. A bitter cup: climate change profile of global production of Arabica and Robusta coffee. Climatic Change, 129 (1-2): 89-101. https://link.springer. com/article/10.1007/s10584-014-1306-x

Cannavo P., Sansoulet J., Harmand J. M., Sile P., Dreyer E., Vaast P., 2011. Agroforestry associating coffee and Inga densiflora results in complementarity for water uptake and decreases deep drainage in Costa Rica. Agriculture Ecosystem and Environment, 140: 1-13.

Carr M. K. V., 2001. The water relations and irrigation requirements of coffee. Experimental Agriculture, 37: 1-36.

Craparo A. C. W., Van Asten P. J. A., Läderach P., Jassogne L. T. P., Grab S. W., 2015. Coffea arabica yields decline in Tanzania due to climate change: Global implications. Agricultural and Forest Meteorology, 207: 1-10.

Čermák J., Prax A., 2001. Water balance of a Southern Moravian floodplain forest under natural and modified soil water regimes and its ecological consequences. Annals of Forest Science, 58: 15-29.

Čermák J., Nadezhdina N., Trcala M., Simon J., 2015. Open field-applicable instrumental methods for structural and functional assessment of whole trees and stands. iForest-Biogeosciences and Forestry, 8 (3): 226.

Davis A. P., Gole T. W., Baena S., Moat J., 2012. The Impact of Climate Change on Indigenous Arabica Coffee (Coffea arabica): Predicting Future Trends and Identifying Priorities. Plos One, 7: 10-14. http://journals.plos.org/plosone/article?id=10.1371/journal. pone.0047981

Ehrenbergerová L., Cienciala E., Kučera A., Guy L., Habrová H., 2016. Carbon stock in agroforestry coffee plantations with different shade trees in Villa Rica, Peru. Agroforestry Systems, 90 (3): 433-445.

Fischer G., Shah M., Tubiello F. N., van Velhuizen H., 2005. Socio-economic and climate change impacts on agriculture: an integrated assessment, 1990-2080. Philosophical Transactions of the Royal Society of London. Series B, Biological sciences, 360: 2067-2083.

Franck N., Vaast P., 2009. Limitation of coffee leaf photosynthesis by stomatal conductance and light availability under different shade levels. Trees, 23: 761-769.

Garab G. (Ed.), 1998. Photosynthesis: Mechanisms and Effects. Springer Science \& Business Media, 4400 p. https://link.springer. com/book/10.1007/978-94-011-3953-3

Harmand J. M., Ávila H., Dambrine E., Skiba U., De Miguel S., Renderos R. V., et al., 2007. Nitrogen dynamics and soil nitrate retention in a Coffea Arabica-Eucalyptus deglupta agroforestry system in Southern Costa Rica. Biogeochemistry, 85 (2): 125-139.

IBC, 1986. Cultura do Café no Brasil - Manual de Recomendações. Instituto Brasileiro do Café - G.E.R.C.A., Rio de Janeiro, 215 p.

IPCC (Intergovernmental Panel On Climate), 2007. Climate change 2007: impacts, adaptation and vulnerability. Cambridge University Press, 987 p. https://www.ipcc.ch/pdf/assessment-report/ar4/ wg2/ar4 wg2 full report.pdf

Khatun K., Imbach P., Zamora J. C., 2013. An assessment of climate change impacts on the tropical forests of Central America using the Holdridge Life Zone (HLZ) land classification system. iForest, 6: 183-189.

Laycock D. H., Wood R. A., 1963. Some observations on soil moisture use under tea in Nysaland. II. The effect of shade trees. Tropical Agriculture, 40: 40-42.

Lin B. B., 2007. Agroforestry management as an adaptive strategy against potential microclimate extremes in coffee agriculture. Agricultural and Forest Meteorology, 144: 85-94. 
Lin B. B., 2010. The role of agroforestry in reducing water loss through soil evaporation and crop transpiration in coffee agroecosystems. Agricultural and Forest Meteorology, 150: 510-518.

Locatelli B., Vignola R., 2009. Managing watershed services of tropical forests and plantations: Can meta-analyses help? Forest Ecology and Management, 258: 1864-1870.

Mes M. G., 1957. Studies on the flowering of Coffea arabica L. III. Various phenomena associated with the dormancy of coffee flower buds. Portugaliae Acta Biologica, 5: 25-44.

Michéli E., Schad P., Spaargaren O., Dent D., Nachtergale F., 2006. World reference base for soil resources. World Soil Resources Reports 103. Food and Agricultural Organization of the United Nations, Rome, 145 p. http://www.fao.org/soils-portal/soil-survey/ soil-classification/world-reference-base/en/

Marengo J. A., 2010. Future climate change scenarios and their application for studies of impacts, vulnerability, and adaptation in Brazil. In: IN Adaptación al cambio climático y servicios ecosistémicos en América Latina. Libro de actas del Seminario Internacional sobre Adaptación al Cambio Climático: el Rol de los Servicios Ecosistémicos, SIAASE 2008, Martínez-Alonso C., Locatelli B., Vignola R., Imbach P. (Eds). CATIE, Serie técnica. Manual técnico, 144 p. http://agents.cirad.fr/pjiimg/bruno.locatelli@cirad.fr/Martinez 2010 Adaptation servicios ecosistemicos.pdf

Moguel P., Toledo V. M., 1999. Biodiversity Conservation in Traditional Coffee Systems of Mexico. Conservation Biology, 13: 11-21.

Morais H., Caramori P. H., Maria A., Ribeiro D. A., Gomes J. C., 2006. Microclimatic characterization and productivity of coffee plants grown under shade of pigeon pea in Southern Brazil. Pesquisa Agropecuária Brasileira, 41: 763-770.

Muller R. A., 1975. L'irrigation précoce, assurance pour une production régulière de haut niveau du caféier Arabica. Café Cacao Thé, 19 (2): 95-122.

Noponen M. R., Haggar J. P., Edwards-Jones G., Healey J. R., 2013. Intensification of coffee systems can increase the effectiveness of REDD mechanisms. Agricultural Systems, 119: 1-9.

Nunes M. A., Bierhuizen J. F., Ploegman C., 1968. Studies on productivity of coffee. I. Effect of light, temperature and $\mathrm{CO}_{2}$ concentration on photosynthesis of Coffea arabica. Acta Botanica Neerlandica, 17(2): 93-102.

Ovalle-rivera O., Läderach P., Bunn C., Obersteiner M., Schroth G., 2015. Projected Shifts in Coffea arabica Suitability among Major Global Producing Regions Due to Climate Change. Plos one, 10 (4): 1-13. Padovan M. P., Cortez V. J., Navarrete L. F., Navarrete E. D., Deffner A. C., Centeno L. G, et al., 2015. Root distribution and water use in coffee shaded with Tabebuia rosea Bertol. and Simarouba glauca DC. compared to full sun coffee in sub-optimal environmental conditions. Agroforestry Systems, 89 (5): 857-868.

Ponce M. G., 2008. Plan de Desarollo Concentrado de Villa Rica 2009-2018. Municipalisas distrital de Villa Rica, provincia Oxapampa - Región Pasco, DESCO, Centro de Estudios y Promoción del Desarollo, Programa Selva Central, 24 p. https://fr.scribd.com/ document/204873138/PDC-VRica

Rice R., 2008. Agricultural intensification within agroforestry: The case of coffee and wood products. Agriculture. Ecosystems \& Environment, 128: 212-218.

Rich P. M., Clark D. B., Clark D. A., Oberbauer S. F., 1993. Longterm study of solar radiation regimes in a tropical wet forest using quantum sensors and hemispherical photography. Agricultural and Forest Meteorology, 65: 107-127.
Rodrigues W. P., Martins M. Q., Fortunato A. S., Rodrigues A. P., Semedo J. N., Simões-Costa M. C., et al., 2016. Long-term elevated air $\left[\mathrm{CO}_{2}\right]$ strengthens photosynthetic functioning and mitigates the impact of supra-optimal temperatures in tropical Coffea arabica and C. canephora species. Global Change Biology, 22 (1): 415-431. https://www.ncbi.nlm.nih.gov/pubmed/26363182

Siles P., Harman J. M., Vaast P., 2010a. Effects of Inga densiflora on the microclimate of coffee (Coffea arabica L.) and overall biomass under optimal growing conditions in Costa Rica. Agroforestry Systems, 78: 269-186.

Siles P., Vaast P., Dreyer E., Harmand J. M., 2010b. Rainfall partitioning into throughfall, stemflow and interception loss in a coffee (Coffea arabica L.) monoculture compared to an agroforestry system with Inga densiflora. Journal of Hydrology, 395 (1): 39-48.

Siebert S. F., 2002. From shade- to sun-grown perennial crops in Sulawesi, Indonesia: implications for biodiversity conservation and soil fertility. Biodiversity and Conservation, 11: 1889-1902.

Slingo J. M., Challinor A. J., Hoskins B. J., Wheeler T. R., 2005. Introduction: food crops in a changing climate. Philosophical Transactions of the Royal Society of London, Series B, Biological sciences, 360: 1983-1989.

Smith E. S. C., 1981. The interrelationships between shade types and cocoa pest and disease problems in Papua New Guinea. In: Advantages, disadvantages and desirable characteristics of shade trees for coffee, cocoa and tea, Beer J., 1987. Agroforestry Systems, 5: 3-13. https://link.springer.com/article/10.1007/BF00046410

Solomon S., Qin M., Manning Z., Chen M., Marquis K. B., Averyt M., et al. (Eds), 2007. Climate change 2007-the physical science basis: Working group I contribution to the fourth assessment report of the IPCC. Cambridge University Press, 996 p. https://www.ipcc. ch/publications and data/publications ipcc fourth assessment report_wg1_report the physical_science_basis.htm

Suárez de Castro F. M., Avilés L., Moreno C., Bolaños M. 1961. Efecto del sombrío en los primeros años de vida de un cafetal. Café de El Salvador, 31: 317-350.

Vaast P., Harmand J. M., Rapidel B., Jagoret P., Deheuvels O., 2016. Coffee and cocoa production in agroforestry - a climate-smart agriculture model. In: Climate change and agriculture worldwide, Torquebiau E. (Ed.), Manley D. (Trad.), Cowan P. (Trad.). Heibelberg, Springer, 209-224.

Vaast P., Charbonnier F., Guillemot J., Maruti G., Devakumar A. S., 2014. Shade level and tree species composition affect water dynamics in coffee agroforestry systems of Western Ghats, India. In: Trees for life: accelerating the impact of agroforestry, abstracts, 3rd World Congress of Agroforestry, Wachira M. A., Rabar B., Magaju C., Borah G. (Eds). Nairobi, World Congress on Agroforestry.

Vaast P., Van Kanten R., Siles P., Angrand J., Aguilar A., 2008. Biophysical interactions between timber trees and Arabica coffee in suboptimal conditions of Central America. In: Toward agroforestry design: an ecological approach, Jose S., Gordon A. M. (Eds). New York, Springer, 133-146. http://www.springer.com/la/book/9781402065712 Van Kanten R., Vaast P., 2006. Transpiration of arabica coffee and associated shade tree species in sub-optimal. Low-altitude conditions of Costa Rica. Agroforestry Systems, 67: 187-202.

Willey R. W., 1975. The use of shade in coffee, cocoa and tea. Horticultural Abstracts, 45 (12): 791-798.

Wintgens J. N., 2004. Coffee: Growing, Processing, Sustainable Production. Wiley-VCH Verlag GmbH \& Co. KGaA, Weinheim, 1040 p. http:// eu.wiley.com/WileyCDA/WileyTitle/productCd-3527332537, subjec$\mathrm{tCd}-\mathrm{HO}$ 40.html 